JOURNAL OF
PLANT PHYSIOLOGY

www.elsevier.de/jplph

\title{
Abscisic acid-induced hydrogen peroxide is required for anthocyanin accumulation in leaves of rice seedlings
}

\author{
Kuo Tung Hung, Deng Guo Cheng, Yi Ting Hsu, Ching Huei Kao*
}

Department of Agronomy, National Taiwan University, Taipei, Taiwan, Republic of China

Received 15 August 2007; received in revised form 22 October 2007; accepted 22 October 2007

KEYWORDS

Abscisic acid;

Anthocyanin;

Hydrogen peroxide;

Oryza sativa

\begin{abstract}
Summary
The role of hydrogen peroxide $\left(\mathrm{H}_{2} \mathrm{O}_{2}\right)$ in abscisic acid (ABA)-induced anthocyanin accumulation in detached and intact leaves of rice seedlings was investigated. Treatment with $A B A$ resulted in an accumulation of anthocyanins in detached rice leaves. Dimethylthiourea, a chemical trap for $\mathrm{H}_{2} \mathrm{O}_{2}$, was observed to be effective in inhibiting ABA-induced accumulation of anthocyanins. Inhibitors of NADPH oxidase (diphenyleneiodonium chloride and imidazole), phosphatidylinositol 3-kinase (wortmannin and LY 294002), and a donor of nitric oxide ( $N$-tert-butyl- $\alpha$-phenylnitrone), which have previously been shown to prevent $A B A$-induced $\mathrm{H}_{2} \mathrm{O}_{2}$ accumulation in detached rice leaves, inhibited $A B A$-induced anthocyanin increase. Exogenous application of $\mathrm{H}_{2} \mathrm{O}_{2}$, however, was found to increase the anthocyanin content of detached rice leaves. In terms of $\mathrm{H}_{2} \mathrm{O}_{2}$ accumulation, intact (attached) leaves of rice seedlings of cultivar Taichung Native 1 (TN1) are ABA sensitive and those of cultivar Tainung 67 (TNG67) are $A B A$ insensitive. Upon treatment with $A B A, \mathrm{H}_{2} \mathrm{O}_{2}$ and anthocyanins accumulated in leaves of TN1 seedlings but not in leaves of TNG67. Our results, obtained from detached and intact leaves of rice seedlings, suggest that $\mathrm{H}_{2} \mathrm{O}_{2}$ is involved in ABA-induced anthocyanin accumulation in this species.

(c) 2007 Elsevier $\mathrm{GmbH}$. All rights reserved.
\end{abstract}

\footnotetext{
Abbreviations: ABA, abscisic acid; c-PTIO, 2-(4-carboxy-2phenyl)-4, 4, 5, 5-tetramethylimidazoline-1-oxyl-3-oxide; DMTU, dimethylthiourea; DPI, diphenyleneiodonium chloride; IMD, imidazole; LY, LY 294002; NO, nitric oxide; PAL, phenylalanine ammonia-lyase; PBN, $N$-tert-butyl- $\alpha$-phenylnitrone; ROS, reactive oxygen species; TN1, Taichung Native 1; TNG67, Tainung 67; WM, wortmannin.

*Corresponding author. Fax: +886223620879 .

E-mail address: kaoch@ntu.edu.tw (C.H. Kao).
}

\section{Introduction}

Anthocyanins, such as delphinidin, cyanidin, and pelargonidin, are water-soluble pigments found in all plant tissues through the plant kingdom and synthesized through the phenylpropanoid and flavonoid pathways (Holton and Cornish, 1995). 
Flavonoids are derived from the aromatic amino acid phenylalanine via cinnamic and coumaric acids. Phenylalanine ammonia-lyase (PAL, EC 4. 3. 1. 5), a key regulatory enzyme of anthocyanin biosynthesis from phenylalanine, is synthesized de novo in many plant tissues. It has been suggested that anthocyanins have antioxidant functions, posses antifugal/antibiotic capabilities, serve a photoprotective role, and allow the plants to develop resistance to environmental stresses, such as UVB radiation, drought, and cold (Chalker-Scott, 1999).

It has been shown that the production of anthocyanins in leaves of Arabidopsis thaliana, Cornus stolonifera, Vigna unguiculata, and Zea mays, and fruits of Vitis vinifera can be induced or up-regulated by low temperatures (Christie et al., 1994; Pietrini and Massacci, 1998; Kubo et al., 1999), drought (Balakumar et al., 1993; Castellarin et al., 2007), and senescence (Field et al., 2001; Hoch et al., 2001). These stresses are known to cause accumulation of abscisic acid (ABA) in plant tissues (Gepstein and Thimann, 1980; Zeevaart, 1980 Lee et al., 1993; Munns and Sharp, 1993; Montero et al., 1997; Yang et al., 2002; Aroca et al., 2003; Xiong and Zhu, 2003).

Fambrini et al. (1993) demonstrated that a sunflower mutant, deficient in carotenoid synthesis and ABA levels, prevents anthocyanin synthesis. Paek et al. (1997) reported that ABA-deficient Viviparous-1 (Vp1) mutants of maize kernels still accumulate anthocyanins. Fluridone is known to inhibit phytoene desaturation and suppress endogenous ABA synthesis (Bartels and Watson, 1978). When developing $V p 1$ kernels were cultured on fluridone to reduce endogenous $A B A$ to near zero levels, anthocyanin synthesis was completely repressed (Paek et al., 1997). Addition of exogenous ABA to fluridone medium induced anthocyanin synthesis in Vp1 kernels (Paek et al., 1997). Recent results also suggest that changes in the content of endogenous $A B A$ may play an important role in the induction of anthocyanin synthesis in regenerated Torenia fournieri shoots (Nagira et al., 2006). Effects of exogenous ABA on anthocyanin accumulation have also been examined. Elevated anthocyanin level has been measured in plants treated with ABA (Pirie and Mullins, 1976; Jiang and Joyce, 2003; Jeong et al., 2004). However, there are reports indicating that anthocyanin level decreased in plants treated with ABA (Guruprasad and Laloraya, 1980; Ozeki and Komamine, 1986). Ithal and Reddy (2004) provided evidence to show that anthocyanin accumulation in rice leaves in response to $100 \mu \mathrm{mol} \mathrm{L}^{-1}$ ABA is genotype-dependent.
Recently, many investigators have focused on the functional aspects of $\mathrm{H}_{2} \mathrm{O}_{2} \cdot \mathrm{H}_{2} \mathrm{O}_{2}$ is a major reactive oxygen species (ROS) generated in plants, which is scavenged by a network of low molecular weight antioxidants and antioxidant enzymes (Asada, 1999). Because $\mathrm{H}_{2} \mathrm{O}_{2}$ is relatively stable and diffusible through membrane, it is generally thought to serve as a signal molecule under various abiotic stresses (Neill et al., 2002), in acclimation to photo-oxidative stress (Karpinski et al., 1999), in plant-pathogen interactions (Levine et al., 1994), and in ABA-induced stomatal closure (Zhang et al., 2001).

We have demonstrated previously that ABA increases the activity of PAL, a key regulatory enzyme of anthocyanin biosynthesis, and promotes senescence in rice leaves (Hung and Kao, 2004, 2005a). Thus, anthocyanin content in rice leaves is expected to be increased by ABA. Our previous work also showed that $\mathrm{H}_{2} \mathrm{O}_{2}$ is involved in ABAincreased PAL activity and ABA-promoted senescence in rice leaves (Hung and Kao, 2004, 2005a). Here we have examined the possible involvement of $\mathrm{H}_{2} \mathrm{O}_{2}$ in $\mathrm{ABA}$-induced anthocyanin accumulation in rice leaves.

\section{Materials and methods}

\section{Plant materials}

Rice (Oryza sativa L., cv. Taichung Native 1 (TN1) or Tainung 67 (TNG67)) seeds were sterilized with 2.5\% sodium hypochlorite for $15 \mathrm{~min}$ and washed extensively with distilled water. These seeds were then germinated in Petri dishes with wetted filter paper at $37{ }^{\circ} \mathrm{C}$ under dark conditions. After $48 \mathrm{~h}$ of incubation, uniformly germinated seeds were selected and cultivated in a $500 \mathrm{~mL}$ beaker containing half-strength Kimura B solution as described previously (Hsu and Kao, 2005). The hydroponically cultivated seedlings were grown for $12 \mathrm{~d}$ in a Phytotron with natural sunlight at $30{ }^{\circ} \mathrm{C}$ day $/ 25^{\circ} \mathrm{C}$ night and $90 \%$ relative humidity. The apical $3 \mathrm{~cm}$ of the third leaf was used in all experiments. A group of 10 segments was floated in a Petri dish containing $10 \mathrm{~mL}$ of test solution. Incubation was carried out at $27^{\circ} \mathrm{C}$ in the dark. In experiments with intact leaves of TN1 and TNG6 7 seedlings, ABA was added to half-strength Kimura B solution at the time when the third leaf was fully expanded.

\section{Determination of anthocyanins and $\mathrm{H}_{2} \mathrm{O}_{2}$}

Quantitative analysis of anthocycnins was performed spectrophotometrically (Kubo et al., 1999). Leaf samples were homogenized with potassium phosphate buffer $(\mathrm{pH}$ $7.8,100 \mathrm{mmol} \mathrm{L}^{-1}$ ). Our preliminary experiments demonstrated that the absorbance of crude rice leaf extract 
peaks at $600 \mathrm{~nm}$. Kubo et al. (1999) claimed that the increase in absorbance at $600 \mathrm{~nm}$ is thought to be due mainly to accumulation of anthocyanins. Thus, for anthocyanin determination, the absorbance of the leaf extract at $600 \mathrm{~nm}$ was measured with a UV-2800 spectrophotometer (Hitachi, Tokyo, Japan). One absorbance unit was defined as the amount of anthocyanins giving an absorbance of 0.1 at $600 \mathrm{~nm}$. The $\mathrm{H}_{2} \mathrm{O}_{2}$ content was measured colorimetrically as described by Jana and Choudhuri (1982). $\mathrm{H}_{2} \mathrm{O}_{2}$ was extracted by homogenizing leaf tissue with phosphate buffer $\left(50 \mathrm{mmol} \mathrm{L}^{-1}, \mathrm{pH} 6.5\right)$ containing $1 \mathrm{mmol} \mathrm{L}^{-1}$ hydroxylamine. The homogenate was centrifuged at $6000 \mathrm{gn}$ for $25 \mathrm{~min}$. To determine $\mathrm{H}_{2} \mathrm{O}_{2}$ content, the extracted solution was mixed with $0.1 \%$ titanium chloride in $20 \%(\mathrm{v} / \mathrm{v}) \mathrm{H}_{2} \mathrm{SO}_{4}$. The mixture was then centrifuged at $6000 \mathrm{~g}$ for $25 \mathrm{~min}$. The absorbance was measured at $410 \mathrm{~nm}$. Using this method, we determined that absorbance increased linearly with the amount of $\mathrm{H}_{2} \mathrm{O}_{2}$, and addition of $\mathrm{H}_{2} \mathrm{O}_{2}$ to extracts resulted in the predicted increase of absorbance, i.e. added $\mathrm{H}_{2} \mathrm{O}_{2}$ was fully recovered. The $\mathrm{H}_{2} \mathrm{O}_{2}$ content was calculated using an extinction coefficient $0.28 \mu \mathrm{mol}^{-1} \mathrm{~cm}^{-1}$. The contents of anthocyanins and $\mathrm{H}_{2} \mathrm{O}_{2}$ were expressed on the basis of initial fresh weight.

\section{Statistical analysis}

Statistical differences between measurements $(n=4)$ on different treatments or at different times were analyzed following Duncan's multiple range test or Student's $t$-test.

\section{Results and discussion}

\section{ABA increases anthocyanin content}

Anthocyanin content in the control leaves remained unchanged during the first 2 of incubation in the dark and increased subsequently (Figure 1). It is clear that ABA-treated rice leaves had higher anthocyanin contents than the control leaves at 2 and $3 \mathrm{~d}$ after treatment (Figure 1).

\section{Effect of dimethylthiourea (DMTU), a chemical trap for $\mathrm{H}_{2} \mathrm{O}_{2}$ and NADPH oxidase inhibitors}

We have previously shown that $\mathrm{ABA}$-induced $\mathrm{H}_{2} \mathrm{O}_{2}$ production in rice leaves is evident $1 \mathrm{~d}$ after treatment (Hung and Kao, 2004). In several plant systems, $\mathrm{H}_{2} \mathrm{O}_{2}$ has been shown to function as a signal molecule (Levine et al., 1994; Rao et al., 1997; Karpinski et al., 1999; Casano et al., 2001; Zhang et al., 2001; Neill et al., 2002). It seems that the accumulation of $\mathrm{H}_{2} \mathrm{O}_{2}$ in rice leaves induced by $A B A$ may play an important role in regulating the

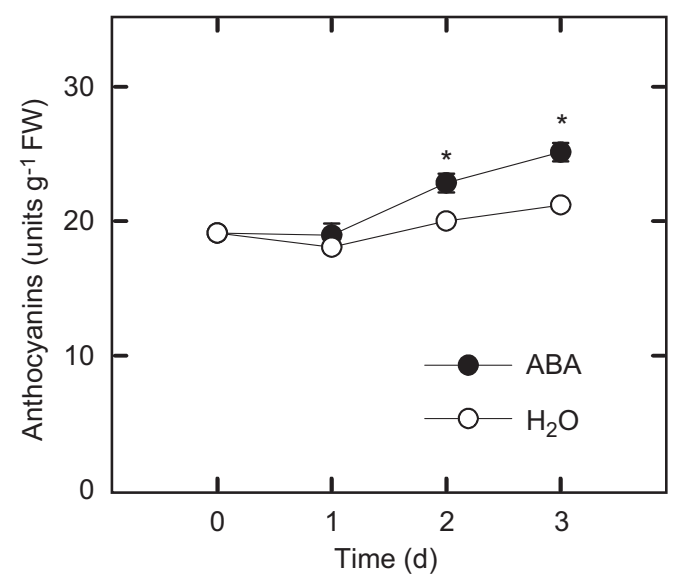

Figure 1. Changes in anthocyanin content in rice leaves treated with either water or $45 \mu \mathrm{mol} \mathrm{L}^{-1} \mathrm{ABA}$ in the dark. Vertical bars represent standard errors $(n=4)$. Asterisks represent values that are significant at $P<0.05$ by Student's $t$-test when compared with water control.

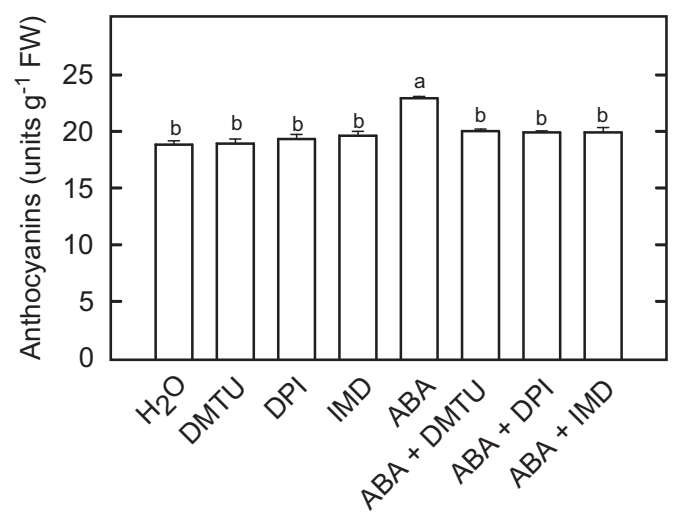

Figure 2. Effect of DMTU, DPI, and IMD on anthocyanin content in rice leaves treated with $A B A$. The concentrations of ABA, DMTU, DPI, and IMD were $45 \mu \mathrm{mol} \mathrm{L}^{-1}$, $5 \mathrm{mmol} \mathrm{L}^{-1}, 25 \mu \mathrm{mol} \mathrm{L}^{-1}$, and $100 \mu \mathrm{mol} \mathrm{L}^{-1}$, respectively. All measurements were determined $2 \mathrm{~d}$ after treatment in the dark. Vertical bars represent standard errors $(n=4)$. Values with the same letter are not significantly different at $P<0.05$, according to Duncan's multiple range test.

increase in anthocyanin content in rice leaves. To test this hypothesis, DMTU, a chemical trap for $\mathrm{H}_{2} \mathrm{O}_{2}$ (Levine et al., 1994; Rao et al., 1997; Casano et al., 2001), was used. As indicated in Figure 2, ABA-induced anthocyanin accumulation was significantly reduced by DMTU. ROS, originating from the plasma-membrane NADPH oxidase, which transfers electrons from cytoplasmic NADPH to $\mathrm{O}_{2}$ to form $\mathrm{O}_{2}^{-}$, followed by dismutation of $\mathrm{O}_{2}^{-}$to $\mathrm{H}_{2} \mathrm{O}_{2}$, has been a recent focus in ROS signaling. There are reports indicating that oxidative burst and the accumulation of $\mathrm{H}_{2} \mathrm{O}_{2}$ are mediated by the 
activation of plasma-membrane NADPH oxidase complex (Ogawa et al., 1997; del Río et al., 1998; Potikha et al., 1999; Pei et al., 2000; OrozcoCárdenas et al., 2001; Jiang and Zhang, 2002). Some chemical inhibitors of the NADPH oxidase complex found in mammalian neutrophils, such as diphenyleneiodonium chloride (DPI) and imidazole (IMD), inhibit the pathogen-, elicitor-, wound-, and ABA-induced accumulation of $\mathrm{H}_{2} \mathrm{O}_{2}$ in plants (Levine et al., 1994; Auh and Murphy, 1995; Bestwick et al., 1997; Alvarez et al., 1998; Orozco-Cárdenas and Ryan, 1999; Jiang and Zhang, 2002). Previously, we also demonstrated that $\mathrm{ABA}$-induced $\mathrm{H}_{2} \mathrm{O}_{2}$ accumulation in rice leaves can be inhibited by lowconcentration $\left(25 \mu \mathrm{mol} \mathrm{L}^{-1}\right)$ DPI and $0.1 \mathrm{mmol} \mathrm{L}^{-1}$ $I M D$, indicating that ABA-dependent $\mathrm{H}_{2} \mathrm{O}_{2}$ generation originated, at least in part, from plasmamembrane NADPH oxidase (Hung and Kao, 2004). As shown in Figure 2, when rice leaves were treated with DPI and IMD, ABA-induced accumulation of anthocyanins was reduced.

\section{Effect of phosphatidylinositol 3-kinase (PI3K) inhibitors}

The mechanism of ROS production and the molecules involved have been well investigated in animal cells, particularly in neutrophils. The NADPH oxidase complex, which consist of many components, is responsible for ROS production in neutrophil cells, and is activated by the binding of phosphatidylinositol 3-phosphate to one of the components (Ellson et al., 2001). Phosphatidylinositol 3-phosphate is a product of PI3K. Jung et al. (2002) and Park et al. (2003) demonstrated that wortmannin (WM) or LY 294002 (LY), inhibitors of $\mathrm{PI} 3 \mathrm{~K}$, inhibited $\mathrm{ABA}$-induced $\mathrm{H}_{2} \mathrm{O}_{2}$ production and stomatal closing and $\mathrm{H}_{2} \mathrm{O}_{2}$ partially reversed the effects of WM or LY on ABA-induced stomatal closing. They suggested that phosphatidylinositol 3-phosphate is important in NADPH oxidasemediated $\mathrm{H}_{2} \mathrm{O}_{2}$ production during $A B A$-induced stomatal closing. In our previous work, we showed that WM or LY prevented $A B A$-induced $\mathrm{H}_{2} \mathrm{O}_{2}$ production (Hung and Kao, 2005b). In the present study, we demonstrated that ABA-induced anthocyanin accumulation in rice leaves was reduced by WM or LY (Figure 3). Meanwhile, we also observed that $\mathrm{H}_{2} \mathrm{O}_{2}$ reversed the effect of WM or LY on ABAinduced increased anthocyanin content (Figure 3 ).

\section{Effect of nitric oxide donor}

Nitric oxide (NO) is a bioactive free radical implicated in a number of physiological processes

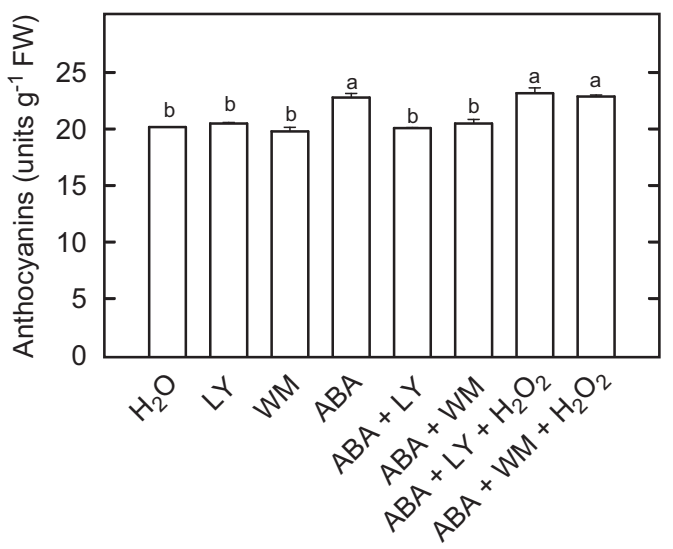

Figure 3. Effect of WM or $L Y$ on anthocyanin content in ABA-treated rice leaves in the presence or absence of $\mathrm{H}_{2} \mathrm{O}_{2}$. The concentrations of $A B A, W M$, and $\mathrm{H}_{2} \mathrm{O}_{2}$ were 45 , $1,100 \mu \mathrm{mol} \mathrm{L}^{-1}$, and $1 \mathrm{mmol} \mathrm{L}^{-1}$, respectively. All measurements were determined $2 \mathrm{~d}$ after treatment in the dark. Vertical bars represent standard errors $(n=4)$. Values with the same letter are not significantly different at $P<0.05$, according to Duncan's multiple range test.

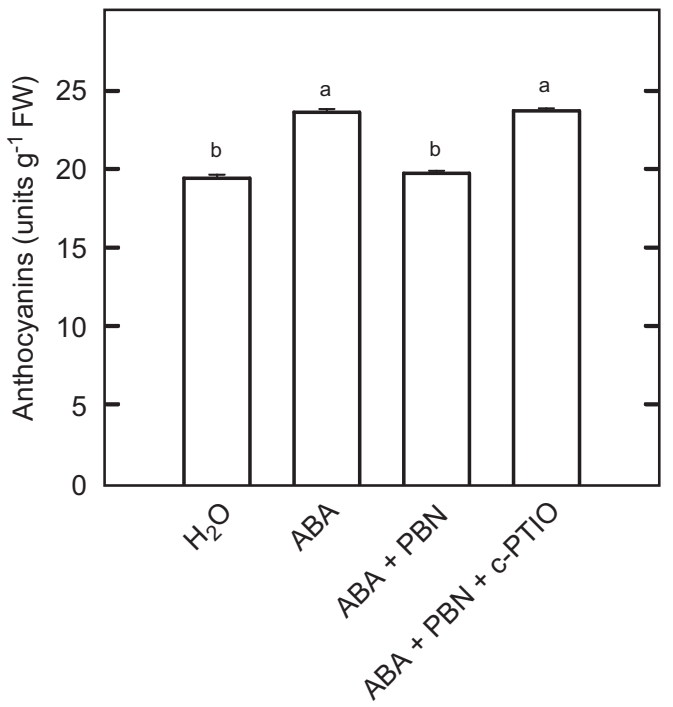

Figure 4. Effect of PBN on anthocyanin content in ABAtreated rice leaves in the presence or absence of c-PTIO. The concentrations of ABA, PBN, and C-PTIO were 45, 100 , and $100 \mu \mathrm{mol} \mathrm{L}^{-1}$, respectively. All measurements were determined $2 \mathrm{~d}$ after treatment in the dark. Vertical bars represent standard errors $(n=4)$. Values with the same letter are not significantly different at $P<0.05$, according to Duncan's multiple range test.

in plants, including growth, development, and defense responses (Lamattina et al., 2003). It has been shown that NO is able to counteract the toxicity of paraquat and diquat, which are known to generate superoxide radicals, in potato and rice leaves (Beligni and Lamattina, 1999; Hung et al., 2002). More recently, we have shown that 
ABA-induced $\mathrm{H}_{2} \mathrm{O}_{2}$ production in rice leaves can be reduced by the NO donor $N$-tert-butyl- $\alpha$-phenylnitrone (PBN) (Hung and Kao, 2003). Here, we show that $\mathrm{PBN}$ is effective in reducing $\mathrm{ABA}$-induced accumulation of anthocyanins in rice leaves (Figure 4). Meanwhile, these PBN effects can be reversed by 2-(4-carboxy-2-phenyl)-4,4,5,5tetramethylimidazoline-1-oxyl-3-oxide (c-PTIO), an

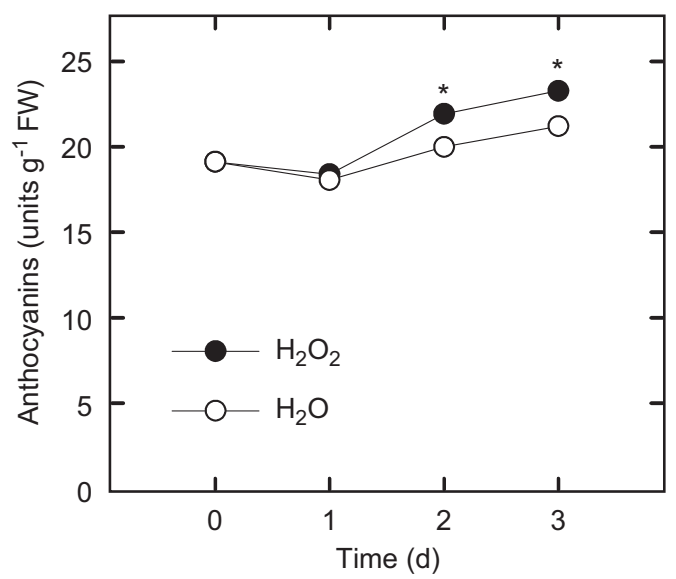

Figure 5. Changes in anthocyanin content in rice leaves treated with either water or $10 \mathrm{mmol} \mathrm{L}^{-1} \mathrm{H}_{2} \mathrm{O}_{2}$ in the dark. Vertical bars represent standard errors $(n=4)$. Asterisks represent values that are significant at $P<0.05$ by Student's $t$-test when compared with water control.
NO-specific scavenger (Figure 4), suggesting that the PBN effects are attributable to NO release.

\section{Effect of exogenous $\mathrm{H}_{2} \mathrm{O}_{2}$}

If $\mathrm{H}_{2} \mathrm{O}_{2}$ indeed plays an important role in $A B A-$ induced accumulation of anthocyanins in rice leaves, exogenous $\mathrm{H}_{2} \mathrm{O}_{2}$ is expected to increase the content of anthocyanins in rice leaves. As shown in Figure 5, it is indeed the case.

\section{ABA induces $\mathrm{H}_{2} \mathrm{O}_{2}$ and anthocyanin accumulations in the leaves of cultivar TN1 seedlings but not in cultivar TNG67}

Figure 6 shows the effect of $A B A$, in the range $5-40 \mu \mathrm{mol} \mathrm{L}^{-1}$, applied over a period of $3 \mathrm{~d}$, on the contents of $\mathrm{H}_{2} \mathrm{O}_{2}$ and anthocyanin in the second leaves of rice seedlings. It is clear that increasing ABA concentration progressively increases anthocyanin content in leaves of TN1 seedlings but not in leaves of TNG 67 (Figure 6B and D). It appears that, in terms of anthocyanin accumulation, TNG67 is an ABA-insensitive cultivar and TN1 is an ABAsensitive cultivar. If $\mathrm{H}_{2} \mathrm{O}_{2}$ is important in regulating anthocyanin accumulation, then $\mathrm{H}_{2} \mathrm{O}_{2}$ content is expected to be increased in ABA-treated seedlings
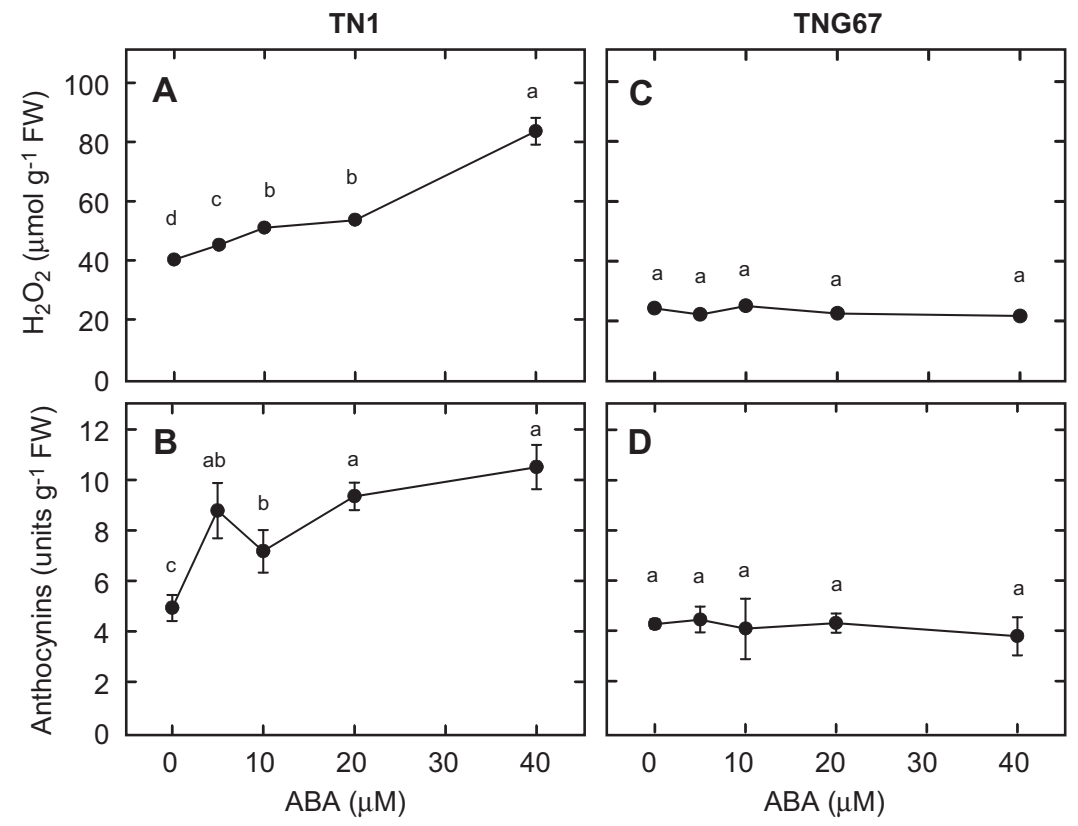

Figure 6. Effect of $A B A$ on the contents of $\mathrm{H}_{2} \mathrm{O}_{2}(A, C)$ and anthocyanins $(B, D)$ in the second leaves of rice seedlings. Rice seedlings were cultivated in Kimura B solution (half-strength) in a Phytotron with natural sunlight at $30{ }^{\circ} \mathrm{C}$ (day)/ $25^{\circ} \mathrm{C}$ (night) at $90 \%$ relative humidity. ABA was added to the Kimura B solution when the third leaves were fully expanded. $\mathrm{H}_{2} \mathrm{O}_{2}$ and anthocyanin content were determined $3 \mathrm{~d}$ after adding $A B A$. Vertical bars represent standard errors $(n=4)$. Values with the same letter are not significantly different at $P<0.05$, according to Duncan's multiple range test. 
of TN1 but not in TNG67. As indicated in Figure 6A and $C$, this is the case.

Treatment with ABA resulted in a two-fold increase in anthocyanin content in the second leaves of TN1 seedlings (Figure 6B). However, ABA caused only about a $3 \%$ increase in anthocyanins (Figure 1). In experiments with intact leaves of TN1 seedlings, ABA was added to culture solution under natural sunlight conditions. However, for detached leaf system, leaf segments were treated with $A B A$ in the dark. It appears that ABA affect on anthocyanin accumulation is more pronounced in the light than in darkness.

\section{Conclusion}

It has been shown that the increase in the content of $\mathrm{H}_{2} \mathrm{O}_{2}$ and the specific activity of PAL, a key enzyme of anthocyanin biosynthesis, occurs 24 and $36 \mathrm{~h}$, respectively, after ABA treatment (Hung and Kao, 2004, 2005a). In the present work, we show that anthocyanin accumulation occurs $48 \mathrm{~h}$ after ABA treatment (Figure 1). Clearly, $\mathrm{H}_{2} \mathrm{O}_{2}$ production is prior to the increase in PAL specific activity and anthocyanin content in ABA-treated detached leaves. In terms of anthocyanins, it was demonstrated that rice seedlings of TN1 are ABA sensitive and those of TNG are $A B A$ insensitive. Upon treatment with $\mathrm{ABA}, \mathrm{H}_{2} \mathrm{O}_{2}$ accumulated in the leaves of TN1 seedlings but not in the leaves of TNG67. This work establishes the links between ABA treatment, $\mathrm{H}_{2} \mathrm{O}_{2}$, and anthocyanins.

\section{Acknowledgments}

This study has been financially supported by the National Science Council of the Republic of China.

\section{References}

Alvarez ME, Penell RI, Meijer PJ, Ishikawa A, Dixon RA, Lamb C. Reactive oxygen intermediates mediate a systemic signal network in the establishment of plant immunity. Cell 1998;92:773-84.

Aroca R, Vernieri P, Irigoyen JJ, Sánchez-Díaz M, Tognoni F, Paerdossi A. Involvement of abscisic acid in leaf and root of maize (Zea mays L.) in avoiding chilling-induced water stress. Plant Sci 2003;165: 671-9.

Asada K. The water-water cycle in chloroplasts: scavenging of active oxygens and dissipation of excess photons. Annu Rev Plant Physiol Plant Mol Biol 1999; 50:601-39.
Auh C-K, Murphy TM. Plasma membrane redox enzyme is involved in the synthesis of $\mathrm{O}_{2}^{-}$and $\mathrm{H}_{2} \mathrm{O}_{2}$ by Phytophthora elicitor-stimulated rose cells. Plant Physiol 1995;107:1241-7.

Balakumar T, Hani Babu V, Paliwal K. On the interaction of UV-B radiation (280-350 $\mathrm{nm}$ ) with water stress in crop plants. Physiol Plant 1993;87:217-22.

Bartels PG, Watson CW. Inhibition of carotenoid synthesis by fluridone and norflurazon. Weed Sci 1978;26: 198-203.

Beligni MV, Lamattina L. Nitric oxide protects against cellular damage produced by methyl violgen herbicides in potato plants. Nitric Oxide Biol Chem 1999;3: 199-208.

Bestwick CS, Brown IR, Bennett MHR, Mansfield JW. Localization of hydrogen peroxide accumulation during the hypersensitive reaction of lettuce cells to Pseudomonas syringae pv phaseolicola. Plant Cell 1997;9:209-21.

Casano LM, Martin M, Sabater B. Hydrogen peroxide mediates the chloroplastic Ndh complex under photooxidative stress in barley. Plant Physiol 2001;125: 1450-8.

Castellarin SD, Pfeiffer A, Sivilotti R, Degan M, Peterlunger $E$, Gaspero GD. Transcriptional regulation of anthocyanins biosynthesis in ripening fruits of grapevine under seasonal water deficit. Plant Cell Environ 2007;30:1381-99.

Chalker-Scott L. Environmental significance of anthocyanins in plant stress responses. Photochem Photobiol 1999;70:1-9.

Christie PJ, Alfenito MR, Walbot V. Impact of low temperature stress on general phenylpropanoid and anthocyanin pathways: enhancement of transcript abundance and anthocyanin pigmentation in maize seedlings. Planta 1994;194:541-9.

del Río LA, Pastori GM, Palma JM, Sandalio LM, Sevilla F, Corpas FJ, et al. The activated oxygen role of peroxisomes in senescence. Plant Physiol 1998;116: 1195-200.

Ellson CD, Gobert-Gosse S, Anderson KE, Davidson K, Erdjument-Bromage $\mathrm{H}$, Tempst $\mathrm{P}$, et al. Ptdlns(3) $\mathrm{P}$ regulates the neutrophil oxidase complex by binding to the PX domain of $4^{\text {phox }}$. Nat Cell Biol 2001;3: 679-82.

Fambrini M, Pugliesi C, Vernieri P, Giuliano G, Baroncelli S. Characteization of a sunflower (Helianthus annuus L.) mutant, deficient in carotenoid synthesis and abscisicacid content, induced by in-vitro tissue culture. Theor Appl Genet 1993;87:65-9.

Field TS, Lee DW, Holbrook NM. Why leaves turn red in autumn. The role of anthocyanins in senescing leaves of red osier dogwood. Plant Physiol 2001;127: 566-74.

Gepstein S, Thimann KV. Changes in the abscisic acid content of oat leaves during senescence. Proc Natl Acad Sci USA 1980;77:2050-3.

Guruprasad KN, Laloraya MM. Effect of pigment precursors on the inhibition of anthocyanin biosynthesis by BA and ABA. Plant Sci Lett 1980;19:73-9. 
Hoch WA, Zeldin El, McCown BH. Physiological signification of anthocyanins during autumnal leaf senescence. Tree Physiol 2001;2:1-8.

Holton TA, Cornish EC. Genetics and biochemistry of anthocyanin biosynthesis. Plant Cell 1995;7:1071-83.

Hsu YT, Kao CH. Abscisic acid accumulation and cadmium tolerance in rice seedlings. Physiol Plant 2005;124: 71-80.

Hung $\mathrm{KT}$, Kao $\mathrm{CH}$. Nitric oxide counteracts the senescence of rice leaves induced by abscisic acid. J Plant Physiol 2003;160:871-9.

Hung $\mathrm{KT}$, Kao $\mathrm{CH}$. Hydrogen peroxide is necessary for abscisic acid-induced senescence of rice leaves. J Plant Physiol 2004;161:1347-57.

Hung $\mathrm{KT}$, Kao $\mathrm{CH}$. Hydrogen peroxide is necessary for abscisic acid-induced $\mathrm{NH} 4+$ accumulation in rice leaves. J Plant Physiol 2005a;162:1022-9.

Hung KT, Kao CH. Phosphstidylinositol 3-phosphate is required for abscisic acid-induced hydrogen peroxide production in rice leaves. Plant Growth Regul 2005b; 45:95-101.

Hung KT, Chang CJ, Kao CH. Paraquat toxicity is reduced by nitric oxide in rice leaves. J Plant Physiol 2002;159: 159-66.

Ithal N, Reddy AR. Rice flavonoid pathway genes, OsDfr and OsAns, are induced dehydration, high salt and $\mathrm{ABA}$, and contain stress responsive promoter elements that interact with the transcription activator, OsC1MYB. Plant Sci 2004;166:1505-13.

Jana S, Choudhuri MA. Glycolate metabolism of the submerged aquatic angiosperm during aging. Aquat Bot 1982;12:345-54.

Jeong ST, Goto-Yamamoto N, Kobayashi S, Esaka M. Effects of plant hormones and shading on the accumulation of anthocyanins and the expression of anthocyanin biosynthetic genes in grape berry skins. Plant Sci 2004;167:247-52.

Jiang $M$, Zhang J. Involvement of plasma membrane NADPH oxidase in abscisic acid- and water stressinduced antioxidant defense in leaves of maize seedlings. Planta 2002;215:1022-30.

Jiang $Y$, Joyce DC. ABA effects on ethylene production. PAL activity, anthocyanin and phenolic contents of strawberry fruit. Plant Growth Regul 2003;39: $171-4$.

Jung J-Y, Kim Y-W, Kwak JM, Hwang J-U, Young J, Schroeder JI, et al. Phosphatidylinositol 3- and 4-phosphate are required for normal stomatal movements. Plant Cell 2002;14:2397-412.

Karpinski S, Reynolds H, Karpinska B, Wingsle G, Creissen G, Mullineaux P. Systemic signaling and acclimation in response to excess excitation energy in Arabidopsis. Science 1999;284:654-7.

Kubo A, Aono M, Nakajima N, Saji H, Tanaka K, Kondo N. Differential responses in activity of antioxidant enzymes to different environmental stresses in Arabidopsis thaliana. J Plant Res 1999;112:279-90.

Lamattina L, García-Mata C, Graziano M, Pagnussat G. Nitric oxide: the versatility of an extensive signal molecule. Annu Rev Plant Biol 2003;54:109-36.
Lee TM, Lur H-S, Chu C. Role of abscisic acid in chilling tolerance of rice (Oryza sativa L.) seedlings. I. Endogenous abscisic acid levels. Plant Cell Environ 1993;16:481-90.

Levine A, Tenhaken R, Dixon RA, Lamb CJ. $\mathrm{H}_{2} \mathrm{O}_{2}$ from the oxidative burst orchestrates the plant hypersensitive disease resistance response. Cell 1994;79:583-93.

Montero E, Eabot C, Barcelo J, Poschenrieder C. Endogenous abscisic acid levels are linked to decreased growth growth of bush bean treated with $\mathrm{NaCl}$. Physiol Plant 1997;101:17-22.

Munns R, Sharp RE. Involvement of abscisic acid in controlling growth in soils of low water potential. Aust J Plant Physiol 1993;20:425-37.

Nagira Y, Ikegami K, Koshiba T, Ozeki Y. Effect of ABA upon anthocyanin synthesis in regenerated torenia shoots. J Plant Res 2006;119:137-44.

Neill SJ, Desikan R, Clarke A, Hurst RD, Hancock JT. Hydrogen peroxide and nitric oxide as signalling molecules in plants. J Exp Bot 2002;53:1237-47.

Ogawa K, Kanematsu S, Asada K. Generation of superoxide anion and localization of CuZn-superoxide dismutase in the vascular tissue of spinach hypocotyls: their association with lignification. Plant Cell Physiol 1997;38:1118-26.

Orozco-Cárdenas ML, Ryan CA. Hydrogen peroxide is generated systemically in plant leaves by wounding and systemin via the octadecanoid pathway. Proc Natl Acad Sci USA 1999;96:6553-7.

Orozco-Cárdenas ML, Narváez-Vásquez J, Ryan CA. Hydrogen peroxide acts as a second messenger for the induction of defense genes in tomato plants in response to wounding, systemin, and methyl jasmonate. Plant Cell 2001;13:179-91.

Ozeki Y, Komamine A. Effects of growth regulators on the induction of anthocyanin synthesis in carrot suspension cultures. Plant Cell Physiol 1986;27:1361-8.

Paek NC, Lee B-M, BVai DG, Cobb BG, Magill CW, Smith JD. Regulatory roles pf abscisic acid for anthocyanin synthesis in maize kernels. Maydica 1997; 42:385-91.

Park KY, Jung J-Y, Park J, Hwang J-U, Kim Y-W, Hwang I, et al. A role for phosphatidylinositol 3-phosphate in abscisic acid-induced reactive oxygen species generation in guard cells. Plant Physiol 2003;132:92-8.

Pei ZM, Murata N, Benning G, Thomine S, Klüsener B, Allen GJ, et al. Calcium channels activated by hydrogen peroxide mediate abscisic acid signaling in guard cells. Nature 2000;406:731-4.

Pietrini F, Massacci A. Leaf anthocyanin content changes in Zea mays L. grown at low temperature. Significance for the relationship between the quantum yield of PSII and the apparent quantum yield of $\mathrm{CO}_{2}$ assimilation. Photosynth Res 1998;58:w13-9.

Pirie A, Mullins MG. Changes in anthocyanin and phenolics content of grapevine leaf and fruit tissues treated with sucrose, nitrate, and abscisic acid. Plant Physiol 1976;58:468-72.

Potikha TS, Collins CC, Johnson DI, Delmer DP, Levine $A$. The involvement of hydrogen peroxide in 
the differentiation of secondary walls in cotton fibers. Plant Physiol 1999;119:849-58.

Rao MV, Paliyath G, Ormrod DP, Murr DP, Watkins CB. Influence of salicylic acid on $\mathrm{H}_{2} \mathrm{O}_{2}$ production, oxidative stress, and $\mathrm{H}_{2} \mathrm{O}_{2}$-metabolizing enzymes. Salicylic acid-mediated oxidative damage requires $\mathrm{H}_{2} \mathrm{O}_{2}$. Plant Physiol 1997;115:137-49.

Xiong L, Zhu J-K. Regulation of abscisic acid biosynthesis. Plant Physiol 2003;133:29-36.

Yang J, Zhang J, Wang Z, Zhu Q, Liu L. Abscisic acid and cytokinins in the root exudes and leaves and their relationship to senescence and mobilization of carbon reserves in rice subjected to water during grain filling. Planta 2002;215:645-52.

Zeevaart JAD. Changes in the levels of abscisic acid and its metabolites in extracted leaf blades of Xanthium strumarium during and after water stress. Plant Physiol 1980;66:672-8.

Zhang X, Zhang L, Dong F, Gao J, Galbraite DW, Song C-P. Hydrogen peroxide is involved in abscisic acid-induced stomatal closure in Vicia faba. Plant Physiol 2001;126: 1438-48. 